\title{
Environmental Impacts of Promoting New Public Transport Systems in Urban Mobility: A Case Study
}

\author{
Abel Ortego $^{* 1}$, Alicia Valero ${ }^{2}$, Alejandro Abadías ${ }^{3}$ \\ ${ }^{1}$ Research Centre for Energy Resources and Consumption (CIRCE), Mariano Esquillor Gomez 15, \\ 50018 Zaragoza, Spain \\ e-mail: aortego@fcirce.es \\ ${ }^{2}$ Research Centre for Energy Resources and Consumption (CIRCE), Mariano Esquillor Gomez 15, \\ 50018 Zaragoza, Spain \\ e-mail: aliciavd@fcirce.es \\ ${ }^{3}$ Research Centre for Energy Resources and Consumption (CIRCE), Mariano Esquillor Gomez 15, \\ 50018 Zaragoza, Spain \\ e-mail: aabadias@fcirce.es
}

Cite as: Ortego, A., Valero, A., Abadías, A., Environmental Impacts of Promoting New Public Transport Systems in Urban Mobility: A Case Study, J. sustain. dev. energy water environ. syst., 5(3), pp 377-395, 2017, DOI: http://dx.doi.org/10.13044/j.sdewes.d5.0143

\begin{abstract}
Urban mobility is highly dependent on private vehicles causing pollution, traffic congestion and traffic accidents. The tram has become one of the most relevant public transport modes in those cities which need to reduce the private vehicle dependency. However, the implementation of this kind of infrastructure must be done carefully to avoid unsuccessful route designs which make the system unfeasible to operate. With the aim of analysing the impact that a tram can cause in a city, an original methodology has been developed, which takes into account the effect of the new transport system implementation on three subimpacts: traffic, public bus and outskirts neighbourhoods. This methodology uses different data sources from urban traffic, environmental and energy systems. The methodology has been applied to the city of Zaragoza (Spain) with a current population of around 700,000 inhabitants. The main results found were that tram line 1 saves $6 \%$ of the annual final energy consumption of urban mobility, urban traffic has decreased by $7.7 \%$ in the city as a whole and by $39.7 \%$ for streets close to the tramway.
\end{abstract}

\section{KEYWORDS}

Urban mobility, Sustainable urban mobility plans, Public transport, Tram, Energy efficiency.

\section{INTRODUCTION}

Around $75 \%$ of the European population lives in urban and metropolitan areas [1]. This fact causes not only an increase in the size of cities but also a growing demand for mobility. Nowadays 2.7 trips are made per person per day [2]. The consequence of this effect can be seen in the passenger-kilometre indicator per inhabitant, which has increased $7 \%$ in the last decade [3]. Moreover, $49 \%$ of urban daily trips are made using private vehicles with their associated negative impact [4].

${ }^{*}$ Corresponding author 
Urban mobility problems are well known. Cities are well connected to each other; however their internal mobility is inefficient and complex because dependence on the private vehicle is very high. Some of the main problems that cause this are: traffic jams, the cost of which is estimated at 80,000 M EUR per year [3]; GHG emissions, where urban mobility generates $23 \%$ of Carbon dioxide $\left(\mathrm{CO}_{2}\right)$ emissions and traffic accidents, where urban mobility causes $38 \%$ of fatal urban traffic collisions [5].

In this global context, local authorities' efforts must be focused on encouraging a change in urban mobility through more sustainable transport systems such as innovative means of public transport, new urban routes for bicycles and pedestrians or the development of new urban models which promote public transport and collaborative smart vehicle use.

Sustainable Urban Mobility Plans (SUMP) is the tool for promoting specific strategies to make urban mobility more sustainable. The consideration of new transport systems in a SUMP is easily done, but to take up its implementation is not free of difficulties [6]. It should be done carefully and with total certainty that the final result is satisfactory, since the associated infrastructures need important investments. Unlucky experiences were that the impact achieved did not comply with what the planned expectations were, for instance those of the tram implementation in Malaga, Sevilla, Parla or Granada [7].

That said, an impact assessment of a new transport system is a difficult task. Different authors have analysed the impact on urban mobility of different public transport systems with a variety of approaches like decision support tools, policy measures, energy efficiency initiatives, economic impacts, performance indicators or specific pilot projects results.

Considering decision support tools, Caufield et al. [8] used Cost Benefit Analysis (CBA), Multi Criteria Analysis (MCA) and Data Envelopment Analysis (DEA) methodologies to analyse the best transport option for a route in Dublin City. Besides, different methodologies to assess impact of different urban mobility systems have been studied, like Lefevre [9] by means of the TRANUS system or Peng et al. [10] using Long Range Energy Alternative Planning LEAP under different scenarios, or SIG tools used by Isabello et al. [11].

From a policy point of view, Rojas-Rueda et al. [12] studied the benefits of adopting new policies to replace car trips with public transport systems under different scenarios, Abrate et al. [13] researched the impact of integrated tariffs to promote public transport, Costa et al. [14] was focused on the gap between public transport fleet assessment and decision-making policies, Aranda-Uson et al. [15] researched the impact of new urban mobility policies from an eco-efficiency point of view and Moriarty et al. [16] the indicators that should be used to measure the impact of urban mobility.

Focusing on efficiency, Okafor et al. [17] analysed how to measure energy efficiency in public transport, comparing energy performance of petrol and diesel bus used in Nigeria. The use of indicators to measure energy efficiency in urban transport Agostino et al. [18] compared results achieved by Performance Measurement System PMS implemented in Milan and Amsterdam.

In the field of new technologies Sauer et al. [19] evaluated the potential benefits that electrical vehicles could cause. Hwang [20] published a revision of development programs for electrical bikes in Taiwan and Singh et al. [21] analysed the barriers and potential to implement hydrogen technologies in transport.

Taking into consideration urban planning, urban mobility has also been studied, like the case of the global assessment method applied by Malla [22] or Kii et al. [23] who compared the influence between urban city shape and urban mobility, whereas Cardenas [24] showed the effects of city morphology in polluted emissions caused by urban mobility. 
With respect to specific interventions, not many studies have been carried out; the influence of Bus Rapid Transit was studied by Bubeck et al. [25] in the case of the Gauteng region. Tricker [26] assessed the environmental impact of London's Cross River Tram but did not quantify the energy of the environmental benefits and Mrkajic et al. [27] researched the impact of park bike promotion in Serbia, while Prud'homme [28] analysed the relationship between congestion and cost studied in the case of Paris subway.

Unlike other studies, this paper offers results about impacts achieved by implementing a new public transport system in a city. This study is not focused on public transport assessment from a Life Cycle Assessment (LCA) point of view but focusing on the environmental and urban air quality benefits throughout the operation lifetime of the transport means. The methodology applied in the City of Zaragoza, shows it as an urban laboratory in which the influence of the new tram line on traffic congestion, urban buses, energy consumption and polluting emissions is tested.

This approach can be very useful for local authorities and policy makers in decisionmaking processes regarding urban mobility planning when adopting new sustainable mobility measures.

\section{DESCRIPTION OF THE CASE STUDY APPLIED}

Zaragoza is the fifth largest Spanish city in terms of population. It is very well placed from a logistic point of view because it is situated in the middle of the way between Madrid - Barcelona and Valencia - Bilbao corridors. Its population has grown by $14 \%$ from 2000 to 2014 . Considering the metropolitan area, $87 \%$ of the population live in the capital city.

Its public transport offer was traditionally based on buses. This transport system was only used in $17.5 \%$ of displacements, a figure far removed from other similar cities like Madrid and Barcelona, with $40 \%$ and 29\%, respectively. One of the main causes of this low usage rate were: the low speed of buses which circulated sharing the road with the rest of vehicles and the growing of the city surface toward perimeter zones which didn't incentivize the use of public transport.

The City of Zaragoza developed a Sustainable Urban Mobility Plan (SUMP), with the aim to improve the mobility in the city, reduce polluting emissions and reduce the use of private vehicles. This SUMP was approved in 2006 and proposed different measures. The main measure from the infrastructure renovation point of view was to develop a Tram line, which connected the northernmost and southernmost city neighbourhoods crossing the city centre. The selection of this project was the subject of great controversy because different alternative options were considered such as the installation of a subway line or high service level buses. However, the tram line 1 option succeeded, becoming finished in 2013.

In 2015 the city updated the SUMP, considering the possibility to build another tram line which connects west and east city areas. To consider the feasibility of this project and support the decision makers in this process, a methodology was developed for assessing the environmental impacts of a tram line and its application to the performance of tram line 1.

Zaragoza tram line 1 has a total length of $12.8 \mathrm{~km}$ and has 25 tram stops in each direction. Figure 1 shows the route of tram line 1 in red.

From a technical point of view, tram line 1 is equipped with a dynamic priority traffic light system. This device gives trams priority over the rest of the traffic at street intersections. As a consequence of this system, the average commercial speed of the tram is $20 \mathrm{~km} / \mathrm{h}$, higher than the average speed of conventional buses which is around $14 \mathrm{~km} / \mathrm{h}$ in most Spanish regional capital cities [29]. 
Besides, this system optimises the traffic light stop time of the rest of traffic, because it encourages trams in both directions to coincide at crossings or street intersections. With respect to accessibility, Table 1 shows the distance of the city population to tram line 1 stops.

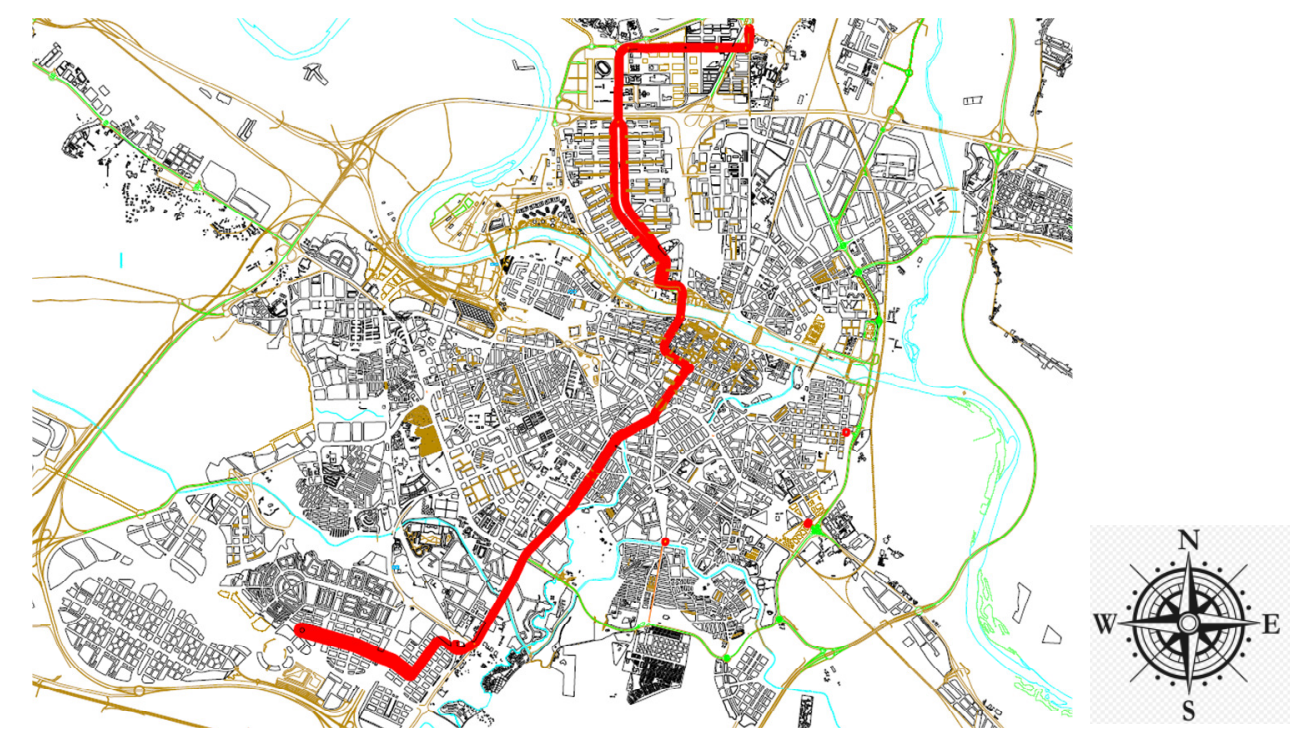

Figure 1. Tram line 1 in Zaragoza

Table 1. Population served by urban tram line 1 [30]

\begin{tabular}{ccc}
\hline Stop distance $[\mathrm{m}]$ & Population served [\%] & Population served [No] \\
\hline 150 & 7.9 & 55,472 \\
300 & 17.3 & 120,738 \\
500 & 27.3 & 189,921 \\
750 & 34.6 & 240,905 \\
\hline
\end{tabular}

Figure 2 shows a circular graphic with the 50 tram stops in both directions. It shows how many people access the tram at each stop.

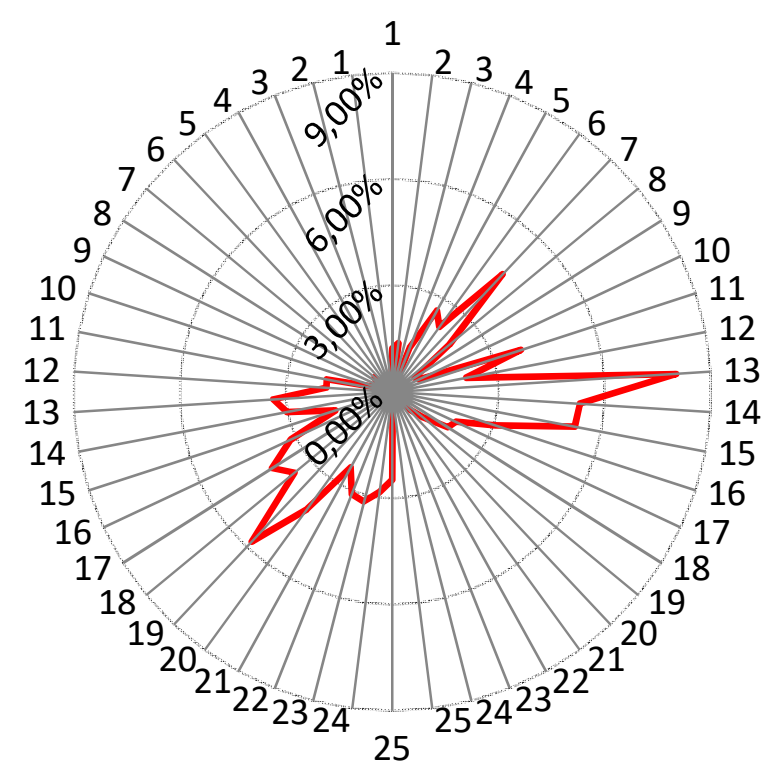

Figure 2. Tram users by tram stop in 2013, authors' compilation using data from [31] 
Considering the 25 tram stops in each direction, in the first five of them in both ways there are 7,722,346 users that access it each year. This is a figure of $21 \%$ of the total number of users.

\section{MATERIALS AND METHODS}

To assess the environmental impact of the tram line, a methodology with a bottomup approach has been made. Global impact is assessed considering three sub-impact categories:

- Traffic impact: assesses the influence of the tram on city traffic as a whole with an assessment area division of $500 \mathrm{~m} \times 500 \mathrm{~m}$;

- Urban bus impact: assesses how many users who used urban buses in the past are now using the tram;

- Outskirts neighbourhood impact: assesses how many users access the tram at the stops located in the outskirts neighbourhoods. This parameter is important, as users with longer transit distances are normally more private vehicle dependent. This means that the impact of a good quality public transport is higher.

To assess the main sub-impacts, the following data can be used: the characteristics of public transport systems, air quality values and traffic flows. These data can be provided by public transport companies, the environmental and urban mobility departments. The three sub-impact assessments must be made before and after the new transport system enters into operation. In the case study, 2009 was chosen as before and 2013 as after.

This decision was made to avoid wrong results as consequence of the unusual traffic flow values that the city experienced during the construction time period of tram line 1 which started in August 2009 and was fully completed in March 2013.

After the sub-impact assessments, an analysis of polluted emissions using permanent measuring stations located in different city areas was done to validate the results.

The impact assessments consider the following set of indicators:

- ES: Final energy savings (MWh/year);

- $\mathrm{AECO}_{2:} \mathrm{CO}_{2}$ emissions avoided (ton/year);

- AECO: Carbon oxide (CO) emissions avoided (ton/year);

- $\mathrm{AENO}_{\mathrm{x}}: \mathrm{NO}_{\mathrm{x}}$ emissions avoided (ton/year);

- $\mathrm{AEPM}_{10}$ : $\mathrm{PM}_{10}$ emissions avoided (ton/year).

Selection of these indicators is motivated by two reasons:

- Final energy saving and $\mathrm{CO}_{2}$ emissions: because they are common indicators used by [32] to assess the environmental performance of a city;

- $\mathrm{CO}, \mathrm{NO}_{\mathrm{x}}$ and $\mathrm{PM}_{10}$ emissions because they are emissions which are regulated by European Legislation about vehicle polluted emissions [33].

As consequence of the amount of different parameters used, there is a range of uncertainty. For this reason a sensitivity analysis was performed with the following variables:

- Average Daily trip Distance made by a commuter in a Private Vehicle (DDPV);

- Average trip distance made in tram for a commuter accessing it in the north or south neighbourhoods (DDTR);

- Displacement share of Private Vehicle in daily urban mobility (DPV).

Subsequently, results were compared to the parameters measured by environmental air quality stations. The specific information of each studied variable and the hypothesis used to assess the impacts in the case study are explained in Table 2.

It is important to note that the data shown in the case study considersthe real occupancy achieved for each one transport system. Real occupancy and full occupancy usually have so different values so real impact must be done without using hypothetical and optimistic figures. Table 3 summarizes used values. 
Table 2. Study parameters and hypothesis

\begin{tabular}{|c|c|c|c|c|}
\hline Variable & Description & Value & Unit & Source \\
\hline$\alpha$ & $\begin{array}{l}\text { Traffic increment due to the effect of } \\
\text { the economic crisis }\end{array}$ & -7 & {$[\%]$} & [34] \\
\hline DD & Daily displacements & $2,001,680$ & [unit/day] & [35] \\
\hline DPV & $\begin{array}{l}\text { Displacement share in } \\
\text { private vehicle }\end{array}$ & 35.7 & {$[\%$ car $]$} & [36] \\
\hline ENPV & $\begin{array}{l}\text { Emission standard for the } \\
\text { average vehicle }\end{array}$ & EURO III & {$[\mathrm{n} / \mathrm{d}]$} & {$[37]$} \\
\hline FC & Fuel consumption in private vehicle & $5.8^{*}$ & {$[1 / 100 \mathrm{~km}]$} & \\
\hline DDPV & $\begin{array}{l}\text { Average daily length made in private } \\
\text { vehicle }\end{array}$ & 18.5 & {$[\mathrm{~km}]$} & {$[37]$} \\
\hline$\beta$ & $\begin{array}{l}\text { Transport use increment due to the } \\
\text { effect of the economic crisis }\end{array}$ & -8.2 & {$[\%]$} & [29] \\
\hline DDPT & Average public transport trip length & 3.58 & {$[\mathrm{~km}]$} & [29] \\
\hline ENB & $\begin{array}{c}\text { Emission standard for the } \\
\text { average bus }\end{array}$ & EURO III & {$[\mathrm{n} / \mathrm{d}]$} & {$[38]$} \\
\hline DDTR & $\begin{array}{l}\text { Travel length for users that access the } \\
\text { tram in the north or } \\
\text { south neighbourhoods }\end{array}$ & $6.4^{\dagger}$ & {$[\mathrm{km}]$} & $\begin{array}{l}\text { (own } \\
\text { hypothesis) }\end{array}$ \\
\hline AMPV & $\begin{array}{c}\text { Alternative transport modality in } \\
\text { north-south neighbourhoods using } \\
\text { private vehicle }\end{array}$ & 60 & {$[\%$ car $]$} & $\begin{array}{c}\text { (own } \\
\text { hypothesis) }\end{array}$ \\
\hline $\mathrm{AMB}$ & $\begin{array}{l}\text { Alternative transport modality in } \\
\text { north-south neighbourhoods using } \\
\text { urban buses }\end{array}$ & 40 & $\begin{array}{l}{[\% \text { public }} \\
\text { transport }]\end{array}$ & $\begin{array}{l}\text { (own } \\
\text { hypothesis) }\end{array}$ \\
\hline $\mathrm{OC}$ & Average car occupancy & 1.2 & [passengers] & [39] \\
\hline
\end{tabular}

Table 3. Energy consumptions and polluting emissions for the tram, bus and private vehicle, authors' compilation using data from [40] and [31]

\begin{tabular}{cccccccc}
\hline \multirow{2}{*}{ Unit } & \multicolumn{3}{c}{ Real occupancy } & \multicolumn{3}{c}{ Full occupancy } \\
\cline { 3 - 7 } & & Tram & Bus & Car $^{\ddagger}$ & Tram & Bus & Car \\
\hline Energy & {$[\mathrm{kWh} /$ passenger] } & 0.18 & 1.19 & 0.47 & 0.02 & 0.21 & 0.14 \\
$\mathrm{CO}_{2}$ & [gr/passenger km] & 71.49 & 328.66 & 128.08 & 8.08 & 60.13 & 38.42 \\
$\mathrm{NO}_{\mathrm{x}}$ & [gr/passenger km] & 0.19 & 5.97 & 0.42 & 0.02 & 1.09 & 0.12 \\
$\mathrm{CO}$ & [gr/passenger km] & $8 \mathrm{E}-4$ & 2.51 & 0.53 & $9 \mathrm{E}-5$ & 0.45 & 0.15 \\
$\mathrm{PM}_{10}$ & [gr/passenger km] & $4.61 \mathrm{E}-3$ & 0.12 & 0.04 & $5 \mathrm{E}-4$ & 0.02 & 0.01 \\
Occupancy & {$[$ passengers] } & 21.93 & 4.94 & 1.2 & $194^{\S}$ & $27^{* *}$ & 4 \\
\hline
\end{tabular}

The total impact is assessed as a sum of the three sub-impacts:

$$
\begin{gathered}
\mathrm{ES}=\mathrm{ES} 1+\mathrm{ES} 2+\mathrm{ES} 3 \\
\mathrm{AECO}_{2}=\mathrm{AE} 1 \mathrm{CO}_{2}+\mathrm{AE} 2 \mathrm{CO}_{2}+\mathrm{AE}_{2} \mathrm{CO}_{2} \\
\mathrm{AECO}=\mathrm{AE} 1 \mathrm{CO}+\mathrm{AE} 2 \mathrm{CO}+\mathrm{AE} 3 \mathrm{CO}
\end{gathered}
$$

\footnotetext{
* Renault Megane $1.9 \mathrm{dCi}$

${ }^{\dagger}$ Calculated as half the total length of line 1

$¥$ Average fuel consumption $5.81 / 100 \mathrm{~km}$ and vehicle under EURO III requirements

$\S$ CAF Urbos $34.32 \mathrm{~m}$

** IvecoUrbanWay $12 \mathrm{~m}$
} 


$$
\begin{gathered}
\mathrm{AENO}_{\mathrm{x}}=\mathrm{AE} 1 \mathrm{NO}_{\mathrm{x}}+\mathrm{AE} 2 \mathrm{NO}_{\mathrm{x}}+\mathrm{AE} 3 \mathrm{NO}_{\mathrm{x}} \\
\mathrm{AEPM}_{10}=\mathrm{AE}_{\mathrm{APM}} \mathrm{AP}_{10}+\mathrm{AE} 2 \mathrm{PM}_{10}+\mathrm{AE} 2 \mathrm{PM}_{10}
\end{gathered}
$$

\section{Assessment of the impact on traffic}

Using traffic flow data from traffic measuring stations $(i)$ the traffic variation $(\Delta T)$ was assessed as the difference of traffic before $\left(T i_{\text {before }}\right)$ and after $\left(T i_{\text {after }}\right)$ the tram line operation. The assessment area was divided into squares which dimensions were $500 \mathrm{~m}$ $\times 500 \mathrm{~m}$. However, because the economic crisis has also had an influence on traffic reduction $(\alpha)$, this fact was taken into account using the following expression:

$$
\Delta T=\sum_{i=1}^{i=n}\left(T i_{\text {before }}\right) \times(1-\alpha)-\sum_{i=1}^{i=n}\left(T i_{\text {after }}\right)
$$

Traffic reduction in \% (TR) is calculated using the following expression:

$$
\mathrm{TR}=\frac{\Delta T}{\left(T i_{\text {before }}\right) \times(1-\alpha)} \times 100
$$

After assessing the traffic reduction, the decrease in private vehicle kilometres is evaluated. Next, the impact on fuel consumption and emission savings are assessed. Energy Saving (ES1) is assessed using the following expression:

$$
\mathrm{ES} 1=\mathrm{Opd} \times \mathrm{DD} \times \mathrm{DPV} \times \mathrm{TR} \times(\mathrm{DDPV} \times \mathrm{ECPV}-\mathrm{DDPT} \times \mathrm{ECPT})
$$

Opd represents the number of operation days in each year. When energy saving is assessed, the emissions reductions are evaluated in the following way:

$$
\begin{aligned}
\mathrm{AE}_{1 C O} & =\mathrm{Opd} \times \mathrm{DD} \times \mathrm{DPV} \times \mathrm{TR} \times\left(\mathrm{DDPV} \times \mathrm{ECO}_{2} \mathrm{PV}-\mathrm{DDPT} \times \mathrm{ECO}_{2} \mathrm{~T}\right) \\
\mathrm{AE} 1 \mathrm{NO}_{\mathrm{x}} & =\mathrm{Opd} \times \mathrm{DD} \times \mathrm{DPV} \times \mathrm{TR} \times\left(\mathrm{DDPV} \times \mathrm{ENO}_{\mathrm{x}} \mathrm{PV}-\mathrm{DDPT} \times \mathrm{ENO}_{\mathrm{x}} \mathrm{T}\right) \\
\mathrm{AE} 1 \mathrm{CO} & =0 \mathrm{pd} \times \mathrm{DD} \times \mathrm{DPV} \times \mathrm{TR} \times\left(\mathrm{DDPV} \times \mathrm{ECO}_{2} \mathrm{PV}-\mathrm{DDPT} \times \mathrm{ECO}_{2} \mathrm{~T}\right) \\
\mathrm{AE}_{\mathrm{PPM}} \mathrm{PM}_{10} & =\mathrm{Opd} \times \mathrm{DD} \times \mathrm{DPV} \times \mathrm{TR} \times\left(\mathrm{DDPV} \times \mathrm{EPM}_{10} \mathrm{PV}-\mathrm{DDPT} \times \mathrm{EPM}_{10} \mathrm{~T}\right)
\end{aligned}
$$

\section{Assessment of the impact on urban bus lines}

To assess the impact of the tram on bus lines, only data from the number of lines $(n)$ that can really be considered affected by tram route line before and after came into operation was analysed. It is important to note that more lines were restructured during these years, but only lines whose routes were significantly affected or completely eliminated by the route of tram line 1 were considered.

As in the case of traffic impact, the impact that economic crisis has had in public transport users $(\beta)$ was also considered. The variation of bus users $(\Delta \mathrm{Ub})$ is calculated using the following expression:

$$
\Delta \mathrm{Ub}=\sum_{i=1}^{i=n}\left(\text { Ubi }_{\text {before }}\right) \times(1-\beta)-\sum_{i=1}^{i=n}\left(\mathrm{Ubi}_{\mathrm{after}}\right)
$$


As soon as the impact on bus users is known, the impact on Energy Saving (ES2) and GHG is quantified:

$$
\mathrm{ES} 2=\Delta \mathrm{Ub} \times \mathrm{DDPT} \times(\mathrm{ECB}-\mathrm{ECT})
$$

The impact on GHG is calculated using the following expressions:

$$
\begin{gathered}
\mathrm{AE}_{2 C_{2}}=\Delta \mathrm{Ub} \times \mathrm{DDPT} \times\left(\mathrm{ECO}_{2} \mathrm{~B}-\mathrm{ECO}_{2} \mathrm{~T}\right) \\
\mathrm{AE} 2 \mathrm{CO}=\Delta \mathrm{Ub} \times \mathrm{DDPT} \times(\mathrm{ECOB}-\mathrm{ECOT}) \\
\mathrm{AE}_{2 \mathrm{NO}_{\mathrm{x}}}=\Delta \mathrm{Ub} \times \mathrm{DDPT} \times\left(\mathrm{ENO}_{\mathrm{x}} \mathrm{B}-\mathrm{ENO}_{\mathrm{x}} \mathrm{T}\right) \\
\mathrm{AE}_{2 \mathrm{PM}_{10}}=\Delta \mathrm{Ub} \times \mathrm{DDPT} \times\left(\mathrm{EPM}_{10} \mathrm{~B}-\mathrm{EPM}_{10} \mathrm{~T}\right)
\end{gathered}
$$

\section{Assessment of the impact on north and south neighbourhoods}

To assess the impact in the north and south areas, the values of users that have accessed the tram in the stops placed at the beginning and the end ${ }^{\dagger \dagger}$ of the line (Un) were assessed. These data were obtained through the e-ticket control that the tram has installed. The impact on Energy Saving (ES3) was assessed using the following expression:

$$
\mathrm{ES} 3=\mathrm{Un} \times \mathrm{DDT} \times[\mathrm{AMPV} \times(\mathrm{ECPV}-\mathrm{ECT})+\mathrm{AMB} \times(\mathrm{ECB}-\mathrm{ECT})]
$$

The emissions of polluting gases avoided is determined using the followings expressions:

$$
\begin{aligned}
& \mathrm{AE}_{3} \mathrm{CO}_{2}=\mathrm{Un} \times \mathrm{DDT} \times\left[\mathrm{AMPV} \times\left(\mathrm{ECO}_{2} \mathrm{PV}-\mathrm{ECO}_{2} \mathrm{~T}\right)+\mathrm{AMB} \times\left(\mathrm{ECO}_{2} \mathrm{~B}-\mathrm{ECO}_{2} \mathrm{~T}\right)\right] \\
& \mathrm{AE} 3 \mathrm{CO}=\mathrm{Un} \times \mathrm{DDT} \times[\mathrm{AMPV} \times(\mathrm{ECOPV}-\mathrm{ECOT})+\mathrm{AMB} \times(\mathrm{ECOB}-\mathrm{ECOT})]
\end{aligned}
$$

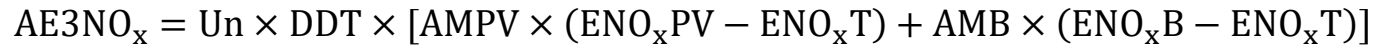

$$
\begin{aligned}
& \mathrm{AE} \mathrm{PM}_{10}=\mathrm{Un} \times \mathrm{DDT} \times\left[\mathrm{AMPV} \times\left(\mathrm{EPM}_{10} \mathrm{PV}-\mathrm{PM}_{10} \mathrm{~T}\right)+\mathrm{AMB} \times\left(\mathrm{EPM}_{10} \mathrm{M}-\mathrm{EPM}_{10} \mathrm{~T}\right)\right]
\end{aligned}
$$

\section{RESULTS}

The results are grouped into six sections:

- Characterisation of public transport system from energy and environmental point of view;

- Influence on traffic flow;

- Tram influence on bus system;

- Influence on polluted emissions;

- Global results;

- Sensitivity analyses of results.

\section{Energy and environment characteristics of public transport systems}

To analyse the impact of the tram, the main figures for the offer and demand of public transport systems were established. Table 4 includes this information.

Table 3 shows the energy consumption and GHG data used both for the bus and tram. It should be stated that when these values are indexed to occupancy, the tram has an

\footnotetext{
${ }^{\dagger}$ There were assessed the 5 stops placed in North and South neighbourhoods
} 
energy consumption per passenger $85 \%$ lower than the bus. Because the tram runs on electricity, in case of polluting emissions, the values are significantly lower.

Table 4. Public transport offer and demand values in 2014, own compilation using data from [31] and [40]

\begin{tabular}{cccc}
\hline & Unit & Bus & Tram \\
\hline Demand (2014) & [users] & $88,161,462$ & $26,869,683$ \\
Offer (2014) & [vehicle-km] & $17,860,895$ & $1,225,036$ \\
Occupancy (2014) & [passengers/km] & 4.94 & 21.93 \\
\hline
\end{tabular}

In the case of the bus, polluting values of $\mathrm{NO}_{\mathrm{x}}, \mathrm{CO}$ and $\mathrm{PM}_{10}$ emitted have been calculated analysing the top values of the European requirements EURO III, which has been compulsory since October 2005 and because the average age of the current bus fleet in Zaragoza is over 10 years [38] the majority of them are under this requirement. In the case of electricity, values for polluting gases were obtained from [41].

\section{The influence on traffic}

One of the first impacts of the implementation of a new transport system is that traffic changes. To assess this impact the city was divided in studied areas of $500 \mathrm{~m} \times 500 \mathrm{~m}$ in which traffic flow measuring stations were installed. In total, 133 traffic flow stations were installed.

Considering specific traffic routes, the Table 5 shows how traffic has changed in the 3 traffic belts. Moreover the influence of the economic crisis on traffic is also shown.

Table 5. Traffic shift in the 2009-2013 period in 3 city belts, source: [42]

\begin{tabular}{ccccc}
\hline & $\begin{array}{c}2009 \\
\text { [vehicle/day] }\end{array}$ & $\begin{array}{c}2013 \\
\text { [vehicle/day] }\end{array}$ & $\begin{array}{c}2013 \text { corrected } \\
\text { [vehicle/day }\end{array}$ & $\Delta$ tram [\%] \\
\hline Traffic in first belt & 70,410 & 60,285 & 65,481 & -7.94 \\
Traffic in second belt & 351,950 & 307,088 & 327,314 & -6.18 \\
Traffic in third belt & 412,690 & 389,249 & 383,802 & 1.41 \\
\hline
\end{tabular}

Table 6. shows the variation of traffic in three points with the highest traffic congestion. Zone $1^{\S \S}$, Zone $2^{* * *}$ and Zone $3^{\dagger \dagger \dagger}$. At these points traffic has been reduced by $32.3 \%, 15.1 \%$ and $18.6 \%$, respectively.

Table 6. Traffic shift in the 2009-2013 period in 3 points with the highest traffic congestion, source: [42]

\begin{tabular}{ccccc}
\hline & $\begin{array}{c}2009 \\
{[\text { vehicle/day] }}\end{array}$ & $\begin{array}{c}2013 \\
{[\text { vehicle/day] }}\end{array}$ & $\begin{array}{c}2013 \text { corrected } \\
{[\text { vehicle/day] }}\end{array}$ & $\Delta$ tram [\%] \\
\hline Zone 1 & 91,630 & 57,690 & 85,216 & -32.3 \\
Zone 2 & 92,040 & 72,640 & 85,597 & -15.13 \\
Zone 3 & 74,300 & 56,280 & 69,099 & -18.55 \\
\hline
\end{tabular}

\footnotetext{
$\ddagger$ Assessed as traffic flows in 2009 minus a $7 \%$ caused by the economic crisis

$\S 41.652207^{\circ} \mathrm{N}-0.879494^{\circ} \mathrm{W}$

*** $41.6591999^{\circ} \mathrm{N}-0.892396^{\circ} \mathrm{W}$

$\dagger+11.653891{ }^{\circ} \mathrm{N}-0.877268{ }^{\circ} \mathrm{W}$
} 
The areas most affected by the tram are the streets closest to the tram route. Table 7 shows the traffic variation in these areas in both directions and as a total. The reduction has been $38.8 \%$ and $40.6 \%$ in the north and south directions, respectively.

Table 7. Traffic shift in the 2009-2013 period in roads next to the tram line, source: [42]

\begin{tabular}{lcccc}
\hline & $\begin{array}{c}2009 \\
\text { [vehicle/day] }\end{array}$ & $\begin{array}{c}2013 \\
\text { [vehicle/day] }\end{array}$ & $\begin{array}{c}\text { 2013 corrected } \\
\text { [vehicle/day] }\end{array}$ & $\Delta$ tram [\%] \\
\hline North direction & 133,290 & 75,845 & 123,960 & -38.81 \\
South direction & 137,330 & 75,804 & 127,717 & -40.64 \\
Both directions & 270,620 & 151,649 & 251,677 & -39.74 \\
\hline
\end{tabular}

To assess the total impact in all cities, Table 8 shows the evolution in overall city traffic.

Table 8. Traffic shift from 2009 to 2013, source: [42]

\begin{tabular}{lcccc}
\hline & 2009 [vehicle/day] & 2013 [vehicle/day] & 2013 corrected [vehicle/day] & $\Delta$ tram [\%] \\
\hline Total city & $2,159,142$ & $1,853,720$ & $2,008,002$ & -7.68 \\
\hline
\end{tabular}

The distribution of these traffic flow changes in the city assessment areas is shown in Figure 3. This classification is shown in 7 colour levels, from light green (reduction higher than $75 \%$ ) to light red (increase higher than 125\%) to represent the evolution of traffic from 2009 to 2013. It can be seen how through the city centre and the avenues which connect south and north neighbourhoods, traffic flow has been reduced. Besides, in the nearest tram line areas traffic has also been reduced. In the west and south-west city areas, the traffic was increased due to two reasons: the creation of new neighbourhoods in the south west city area and the improvement of city access ways for these zones. It must be said though that this traffic growth does not come to the city centre.

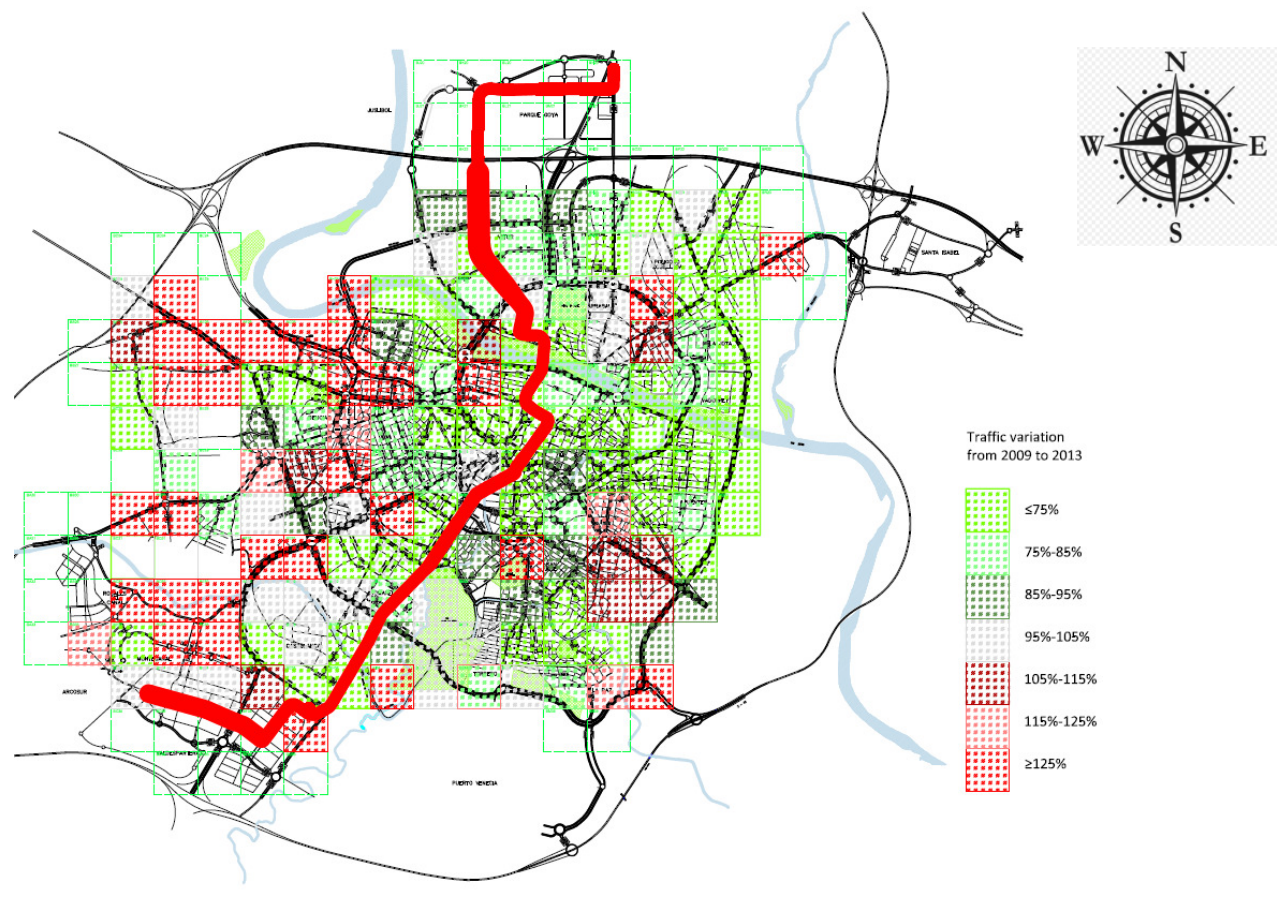

Figure 3. Traffic flow evolution from 2009 to 2013, source: own elaboration 


\section{The influence on the urban bus transport system}

From 2009 to now, the bus has experienced a significant decline in users. In 2009 the figure was 120,340,863 and in 2013 it was $91,413,241$. This is a reduction of $24 \%$ of the users. However not all reductions can be considered due to the tram for 3 reasons:

- As a consequence of the economic crisis, there was a reduction of $8.2 \%$ in public transport users [29];

- In parallel with the implementation of the tram line, all bus lines were restructured to increase their economic feasibility;

- Not all bus lines have been affected by the tram line route.

Therefore, in this study only the influence on passenger reduction in bus routes that were cancelled or significantly modified by the tram line were analysed. The totals for the bus lines affected by the tram are shown in Table 9 .

Table 9. User shift in bus lines affected by the tram line, source: [40]

\begin{tabular}{ccccc}
\hline Line & 2009 & 2013 & $\Delta 2009-2013$ & $\Delta 2009-2013$ \\
\hline 20 & $5,741,559$ & $1,242,901$ & $-4,498,658$ & $-78.35 \%$ \\
23 & $9,127,543$ & $5,119,279$ & $-4,008,264$ & $-43.91 \%$ \\
30 & $7,782,923$ & $2,109,616$ & $-5,673,307$ & $-72.89 \%$ \\
40 & $7,420,896$ & $3,514,678$ & $-3,906,218$ & $-52.64 \%$ \\
43 & 457,912 & 273,282 & $-184,630$ & $-40.32 \%$ \\
44 & $1,903,221$ & $1,696,735$ & $-206,486$ & $-10.85 \%$ \\
$\mathrm{C} 2$ & 409,869 & 103,242 & $-306,627$ & $-74.81 \%$ \\
\hline
\end{tabular}

These lines had a reduction of 18,784,190 users. However, considering the effect of the economic crisis, it can be considered that the number of users who changed from the bus to tram is $16,090,988$.

\section{The influence on polluting gases}

One of the most important effects to corroborate the positive influence of new transport systems in a city is the evolution in polluting gases. The change cannot be only attributed to the tram, because more urban mobility measures have been implemented under the Zaragoza Sustainable Urban Mobility Plan in recent years. But data evolution is very important from a perspective of the extent of the impact of these measures.

This part shows how polluting emissions have changed in the city from $1^{\text {st }}$ January 2009 to $31^{\text {st }}$ December 2013. The following table shows the figures obtained in the 6 polluting gases emission measuring stations which measured the main polluted gases emitted by vehicles: $\mathrm{CO}, \mathrm{NO}_{\mathrm{x}}$ and $\mathrm{PM}_{10}$.

From the data in Table 10, it can be said that all stations measured a reduction in polluted emissions, the highest reduction being in the case of $\mathrm{PM}_{10}$. As an average among the six stations, the emissions of $\mathrm{CO}, \mathrm{NO}_{2}$ and $\mathrm{PM}_{10}$ have decreased in the city by $17.73 \%$, $8.83 \%$ and $49.11 \%$, respectively.

The position of measuring stations and the evolution of $\mathrm{CO}_{2}$ emissions in assessment areas are shown in Figure 4. The classification is represented in 7 colour levels, from light green to light red. In Station 1 which is placed just in the city centre the emission reduction has been $11.67 \%, 9.45 \%$ and $47.85 \%$ for $\mathrm{CO}, \mathrm{NO}_{\mathrm{x}}$ and $\mathrm{PM}_{10}$, respectively. Comparing Figure 3 and Figure 4 it can be said that although in some cases traffic flow has increased, the improvement of emissions requirements along the study periods balances this fact. 
Table 10. Evolution of the main polluting gases from 2009 to 2013, author's compilation using data from [43]

\begin{tabular}{lccccccccc}
\hline & \multicolumn{2}{c}{$\mathrm{CO}\left[\mathrm{mg} / \mathrm{m}^{3}\right]$} & $\mathrm{NO}_{\mathrm{x}}\left[\mu \mathrm{g} / \mathrm{m}^{3}\right]$ & $\mathrm{PM}_{10}\left[\mu \mathrm{g} / \mathrm{m}^{3}\right]$ & $\Delta \mathrm{CO}$ & \multicolumn{2}{c}{$\Delta \mathrm{NO}_{\mathrm{x}}$} & \multicolumn{1}{c}{$\Delta \mathrm{PM}_{10}$} \\
\cline { 2 - 10 } & 2009 & 2013 & 2009 & 2013 & 2009 & 2013 & $09-13$ & $09-13$ & $09-13$ \\
\hline Station 1 & 0.27 & 0.24 & 31.22 & 28.27 & 32.04 & 16.71 & $-11.67 \%$ & $-9.45 \%$ & $-47.85 \%$ \\
Station 2 & 0.24 & 0.21 & 29.44 & 25.11 & 37.26 & 22.73 & $-12.92 \%$ & $-14.71 \%$ & $-38.98 \%$ \\
Station 3 & 0.24 & 0.21 & 25.43 & 21.12 & 30.01 & 16.29 & $-12.55 \%$ & $-16.95 \%$ & $-45.73 \%$ \\
Station 4 & 0.33 & 0.24 & 30.61 & 29.90 & 40.28 & 17.65 & $-26.23 \%$ & $-2.31 \%$ & $-56.19 \%$ \\
Station 5 & 0.19 & 0.16 & 24.09 & 23.35 & 38.27 & 17.13 & $-18.19 \%$ & $-3.09 \%$ & $-55.24 \%$ \\
Station 6 & 0.29 & 0.23 & 36.55 & 33.93 & nd & nd & $-21.84 \%$ & $-7.16 \%$ & nd \\
\hline
\end{tabular}

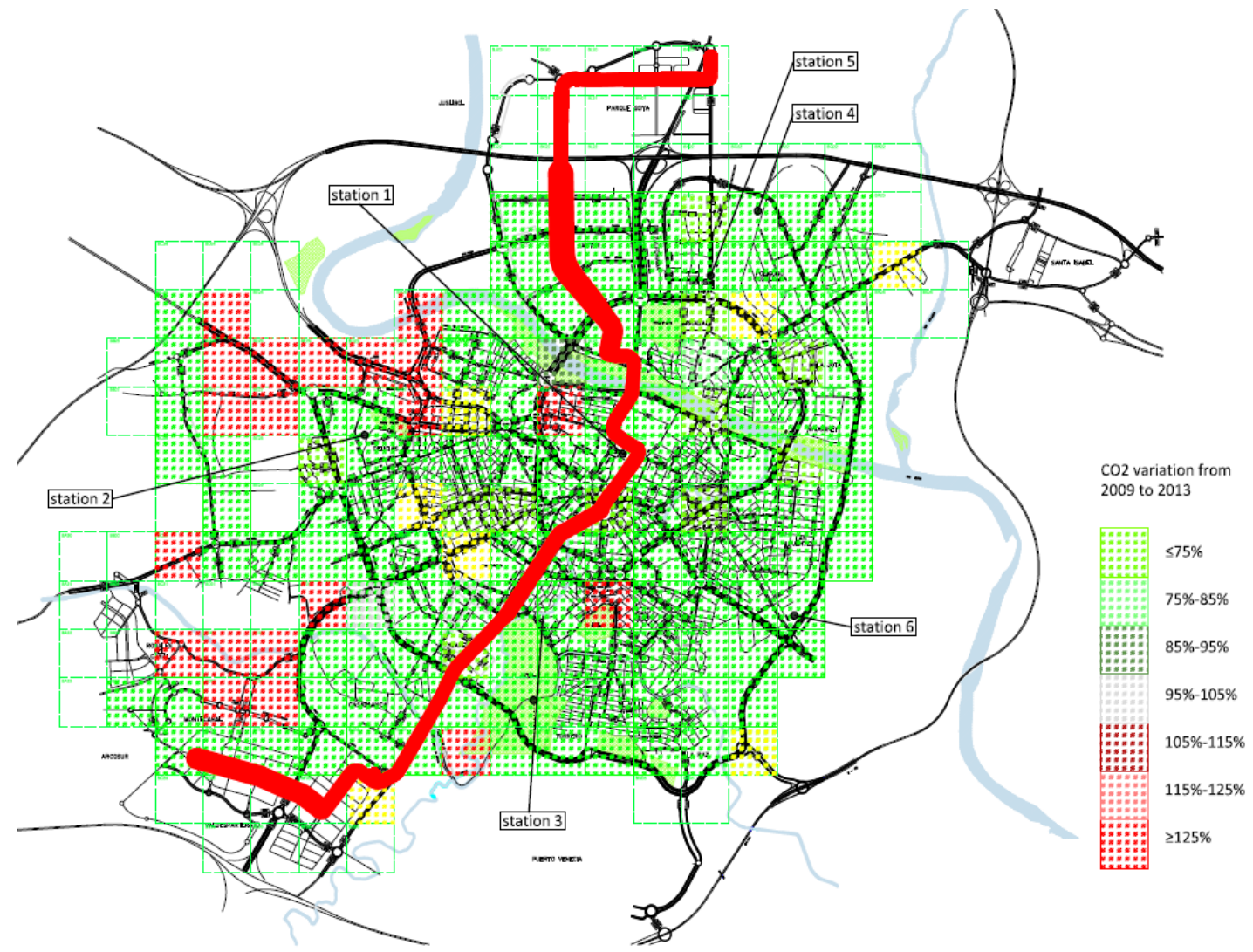

Figure 4. Location of measuring station and $\mathrm{CO}_{2}$ evolution in assessment areas

\section{Total influence of tram line 1}

The global results considering the three studied sub impacts are summarized in the Table 11.

Table 11. Impact of the tram line in different categories

\begin{tabular}{cccc}
\hline & Traffic reduction & Bus-tram migration & N-S city areas \\
\hline Energy saving & $110,703.15$ & $58,431.34$ & $20,527.15$ \\
[MWh/year] & $29,347.35$ & $14,814.35$ & $4,865.78$ \\
$\mathrm{CO}_{2}$ saving [ton/year] & 97.23 & 332.65 & 86.83 \\
$\mathrm{NO}_{\mathrm{x}}$ saving [ton/year] & 136.96 & 144.43 & 47.03 \\
$\mathrm{CO}$ saving [ton/year] & 10.47 & 6.61 & 2.42 \\
$\mathrm{PM}_{10}$ saving [ton/year] & &
\end{tabular}


Traffic reduction in the city is the highest sub-impact, avoiding 10.47 ton $\mathrm{PM}_{10}$ /year, next the migration of users from bus to tram with a reduction of 6.61 ton $\mathrm{PM}_{10} /$ year and the impact on the north and south neighbourhoods with a reduction of $\mathrm{PM}_{10} /$ year. Table 12 shows the total values in energy savings and GHG reduction.

Table 12. Global impact of the tram line

\begin{tabular}{cc}
\hline Indicator & Value \\
\hline Energy saving [MWh/year] & $189,661.64$ \\
$\mathrm{CO}_{2}$ saving [ton/year] & $49,027.48$ \\
$\mathrm{NO}_{\mathrm{x}}$ saving [ton/year] & 516.71 \\
$\mathrm{CO}$ saving [ton/year] & 328.42 \\
$\mathrm{PM}_{10}$ saving [ton/year] & 19.51 \\
\hline
\end{tabular}

\section{Sensitivity analysis}

As mentioned in the methodology, there is uncertainty about the values considered for the following variables: Daily Displacement in Private Vehicle (DDPV) (km), average distance for trips made by users who take the tram in the north and south neighbourhoods (DDT) $(\mathrm{km})$ and Alternative Modality share to tram in Private Vehicle (AMPV) (\%). For that reason a sensitivity analysis of the total results according to these parameters is required.

Figure 5 shows the impact on energy saving with respect to a change in the 3 study variables from $-15 \%, 7.5 \%, 7.5 \%$ to $15 \%$ compared to the reference value shown in Table 2.

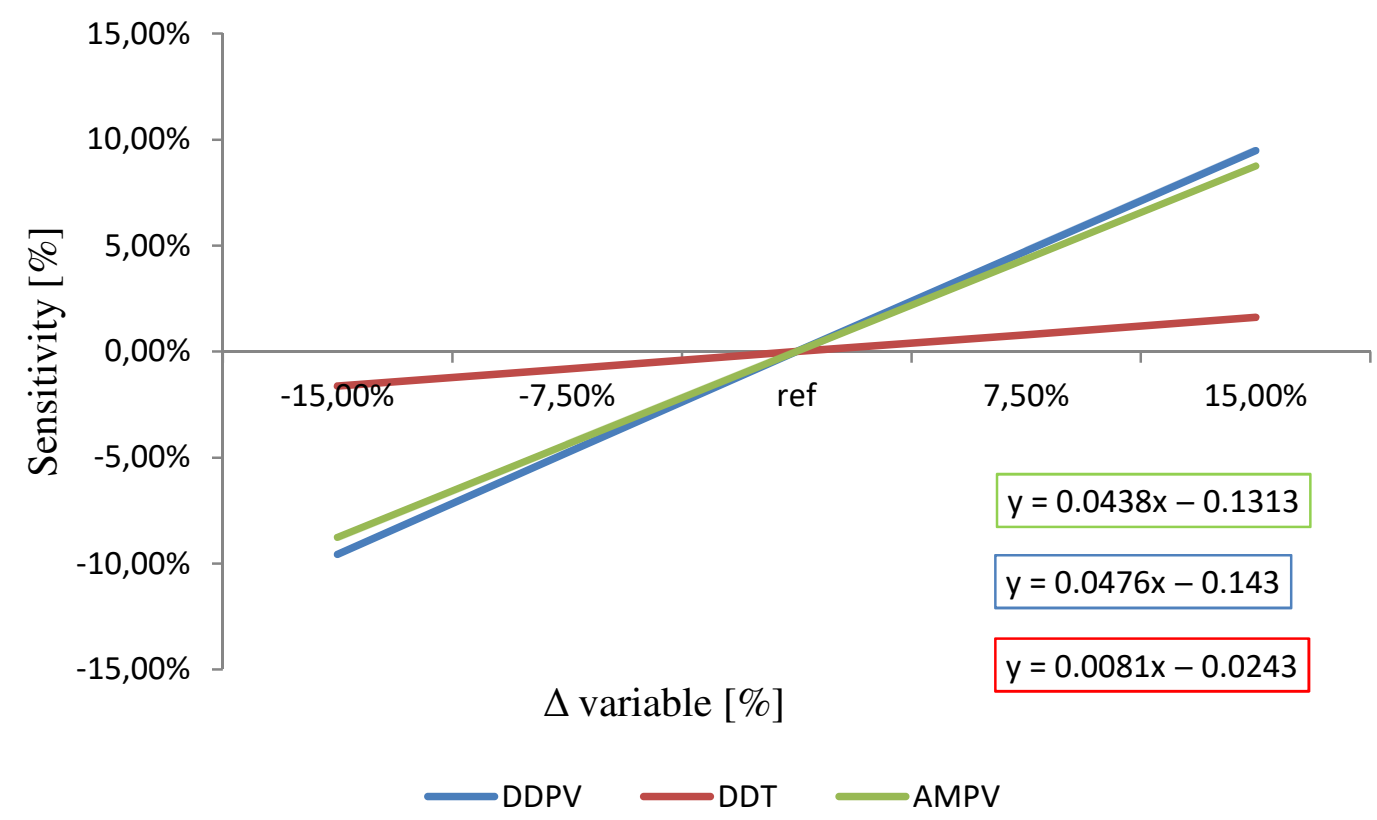

Figure 5. Sensitivity analysis of energy savings DDVP, DDTR, MVP

Figure 6 shows the sensitivity of $\mathrm{CO}_{2}$ emissions with respect to the same variables.

Table 13 shows the total impact of tram line 1 in energy savings and $\mathrm{CO}_{2}$ emissions with the tolerance assessed in the sensitivity analysis.

According to this sensitivity analysis, it can be stated that the achieved results have an accuracy of around $10 \%$. The final values depend mainly on the following variables: Daily Distance in Private Vehicle (DDPT), Daily Distance of Tram Trips (DDT) and 
Alternative Mobility to Private Vehicle in the furthest neighbourhoods (AMPV). A variation in DDT is less sensitive than variables DDPT and AMPV. In these last two, change of $15 \%$ in their values causes change of up to $10 \%$ in emissions and energy savings.

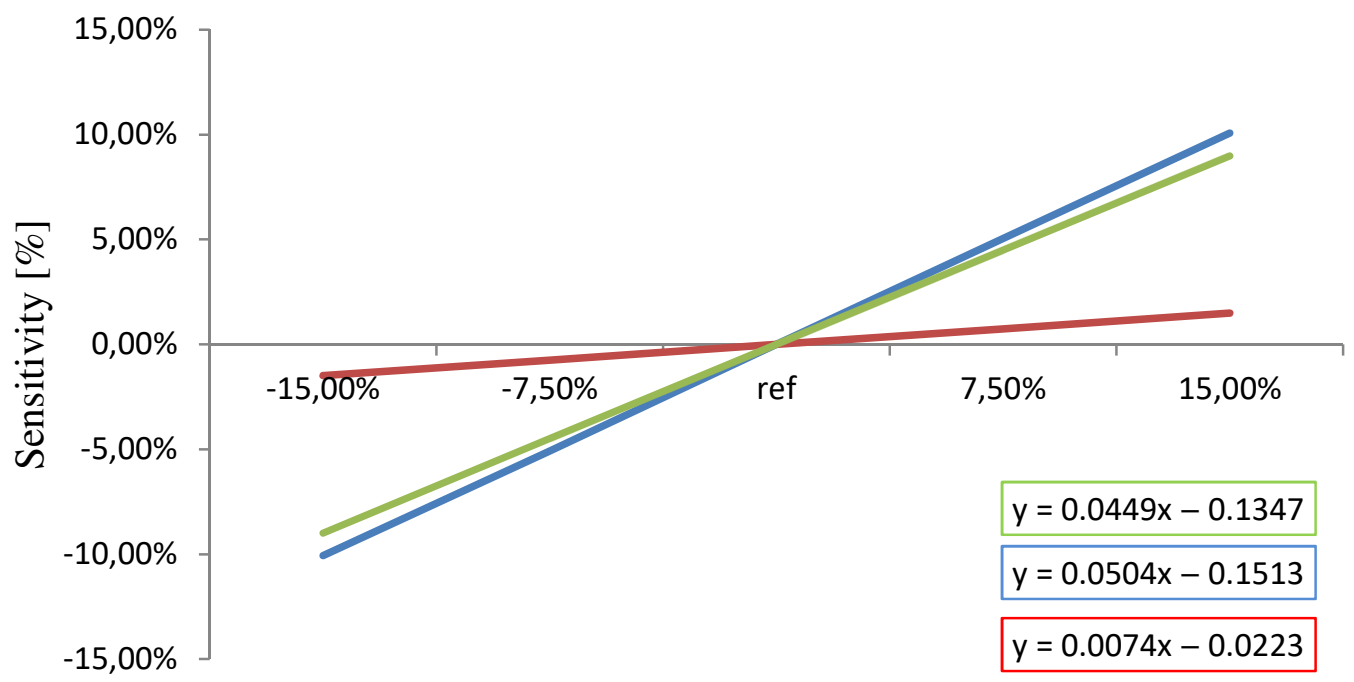

$\Delta$ variable [\%]

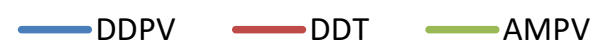

Figure 6. Sensitivity analysis of $\mathrm{CO}_{2}$ emissions DDVP, DDTR, MVP

Table 13. Impact of tram line 1

\begin{tabular}{cc}
\hline Indicator & Value \\
\hline Energy saving [MWh/year] & $189,661.64 \pm 9.5 \%$ \\
$\mathrm{CO}_{2}$ emission saving [ton/year] & $49,027.48 \pm 10 \%$ \\
\hline
\end{tabular}

To know the impact regarding the urban mobility sectors, the results are compared with yearly energy consumption and $\mathrm{CO}_{2}$ emissions of the urban mobility sector in the City of Zaragoza in 2009. This comparison is shown in Table 14. The data comes from the Baseline Emission Inventory of Zaragoza under the Sustainable Energy Action Plan approved in 2009.

Table 14. Energy savings and $\mathrm{CO}_{2}$ emission reduction caused by tram line 1

\begin{tabular}{cccc}
\hline Indicator & $\begin{array}{c}\text { Urban mobility sector } \\
\text { energy consumption } \\
\text { (AGENDA_21 2015) }\end{array}$ & Savings & Reduction \\
\hline Energy [MWh/year] & 3.164 .097 & $189,661.64 \pm 9.5 \%$ & $5.9 \%$ \\
$\mathrm{CO}_{2}$ emissions [ton/year] & 810.210 & $49,027.48 \pm 10 \%$ & $6 \%$ \\
\hline
\end{tabular}

\section{CONCLUSIONS AND DISCUSSION}

The improvement of urban mobility is one of the $21^{\text {st }}$ century challenges for urban planners and policy makers. Accordingly, the promotion of non-polluting transport systems alternative to private vehicles is being encouraged in cities.

In the assessment process of different alternatives and urban mobility measures, different approaches can be considered: economic, social, geographical or environmental 
ones. It is well known that to achieve a successful result, all of them have to be considered. However the assessment of the future impacts depends on variables that sometimes are difficult to predict like the future number of users or traffic reduction. This fact is especially important in those projects where high investments are required, such as when new public transport systems are considered.

Moreover, the implementation of a new public transport system across the main city congestion areas has an impact on other transport systems like conventional buses or private vehicles. Indeed, if the new system is well designed, a positive impact on the city is ensured: reduction of traffic, less vehicles in the city, less congestion, and better air quality and mobility. As widely demonstrated, mobility becomes more sustainable, the greater the barriers to private vehicle use and the better the public transport system offered as an alternative. So push and pull measures must be combined to improve the mobility.

This paper has shown a methodology to assess this impact by combining the effect of three subimpacts (traffic, public bus and outskirts neighbourhoods) from an environmental point of view. Such effects were selected because they are especially relevant, as demonstrated in this paper, when new transport means are implemented in cities. Through the new transport system, traffic should be reduced, traditional public mobility means such as buses become displaced and commuting with private cars from citizens living in the outskirts of the city diminish.

This approach supports the decision making process to develop a new transport system in a city. Moreover, its outputs are also helpful to disseminate its advantages among society. Indeed, in a period of time in which mayors and councillors are working to improve cities' quality of life, the presented methodology demonstrates how it can be reliably quantified when a new public transport system is implemented.

Finally the results offered in this study make that the case study be considered as a valuable best practice for policy makers and urban planners. In the case of Zaragoza the implementation of tram line 1 has been a resounding success for the following main reasons:

- The optimum design of the line which connects the north and south neighbourhoods through mobility attraction points (like the city centre, the hospital, the university, one commercial centre and the football stadium);

- The implementation of a traffic priority system which enables a high commercial speed;

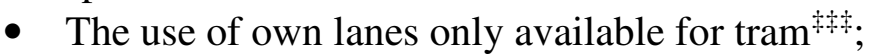

- The reduction of lanes to be used for private vehicles.

These facts have encouraged the reduction of other transport systems like private vehicles or buses and the improvement of urban mobility. This improvement can be corroborated by other studies like [44] in which Zaragoza was considered the city with the least traffic congestion of the 60 cities studied.

As a consequence, the impact of each commuter is now much lower with respect to the previous urban transport system. Moreover, as there are no direct emissions, the environmental air quality is now much better. In the presented case study with the implementation of tram line 1 in the City of Zaragoza the following main results have been achieved:

- Final energy saving of $189,661.64 \mathrm{MWh} \pm 9.5 \%$. This figure is equivalent to the saving of 19.6 million litres of diesel fuel;

- Considering the final annual energy consumption of all tram infrastructures (vehicles, tram stops and garages) this figure is 9,068.02 MWh/year. If this value

$\$ \$$ This lanes were designed to be also used for ambulances, fire trucks or police vehicles in emergency circumstances 
is compared with the annual energy savings made by tram line 1, it can be said that for each unit of energy consumed by the tram, it saves 21 energy units;

- Avoided emissions of $49,027.48 \pm 10 \% \mathrm{CO}_{2}$ tons. This is a reduction of $6 \%$ with respect to the total urban mobility emissions;

- Traffic reduction of $7.68 \%$ in the city as a whole and $39.74 \%$ in the city centre;

- A reduction in polluting gases such as $\mathrm{NO}_{\mathrm{x}}, \mathrm{CO}$ and $\mathrm{PM}_{10}$ of 491.72; 293.21 and 16.82 ton/year respectively. This has contributed to reducing $\mathrm{NO}_{\mathrm{x}}, \mathrm{CO}$ and $\mathrm{PM}_{10}$ emissions by $17.73 ; 8.83$ and $49.11 \%$ respectively from 2009 values.

\section{ACKNOWLEDGEMENT}

The authors acknowledge the projects Z2020xMUS (exp 907.740/2014) and IREZAR (exp 714.733/2015) financed by the Environmental Agency of Zaragoza. Thanks to these projects, it has been possible to access the data sources used in this work.

\section{NOMENCLATURE}

\begin{tabular}{|c|c|c|}
\hline AMPV & modality share alternative to tram: private vehicle & {$[\%]$} \\
\hline AMB & modality share alternative to tram: bus & [\%] \\
\hline DDT & $\begin{array}{l}\text { average distance for trips made by users who take } \\
\text { the tram in the north and south neighbourhoods }\end{array}$ & {$[\mathrm{km}]$} \\
\hline DPV & displacement share in private vehicle & {$[\%]$} \\
\hline DDPV & daily displacement in private vehicle & {$[\mathrm{km}]$} \\
\hline DDPT & daily displacement in public transport & {$[\mathrm{km}]$} \\
\hline DDTR & daily displacement in tram & {$[\mathrm{km}]$} \\
\hline DPV & displacement share in private vehicle & {$[\%]$} \\
\hline ECPV & energy consumption in private vehicle & [kWh/passenger $\mathrm{km}]$ \\
\hline ECB & energy consumption in bus & [kWh/passenger $\mathrm{km}]$ \\
\hline ECT & energy consumption in tram & [kWh/passenger $\mathrm{km}]$ \\
\hline $\mathrm{ECO}_{2} \mathrm{~B}$ & $\mathrm{CO}_{2}$ emissions of bus & [ $\mathrm{g} \mathrm{CO}_{2} /$ passenger $\left.\mathrm{km}\right]$ \\
\hline $\mathrm{ECO}_{2} \mathrm{PV}$ & $\mathrm{CO}_{2}$ emissions of private vehicle & [g CO $2 /$ passenger $\mathrm{km}$ ] \\
\hline $\mathrm{ECO}_{2} \mathrm{~T}$ & $\mathrm{CO}_{2}$ emissions of tram & [ $\mathrm{g} \mathrm{CO}_{2} /$ passenger $\left.\mathrm{km}\right]$ \\
\hline ECOB & $\mathrm{CO}$ emissions of bus & [ $\mathrm{g} \mathrm{CO}_{2} /$ passenger $\left.\mathrm{km}\right]$ \\
\hline ECOPV & $\mathrm{CO}$ emissions of private vehicle & {$\left[\mathrm{g} \mathrm{CO}_{2} /\right.$ passenger $\left.\mathrm{km}\right]$} \\
\hline ECOT & $\mathrm{CO}$ emissions of tram & [g CO $2 /$ passenger $\mathrm{km}]$ \\
\hline $\mathrm{ENO}_{\mathrm{x}} \mathrm{B}$ & $\mathrm{NO}_{\mathrm{x}}$ emissions of bus & {$\left[\mathrm{g} \mathrm{CO}_{2} /\right.$ passenger $\left.\mathrm{km}\right]$} \\
\hline $\mathrm{ENO}_{\mathrm{x}} \mathrm{PV}$ & $\mathrm{NO}_{\mathrm{x}}$ emissions of private vehicle & {$\left[\mathrm{g} \mathrm{CO}_{2} /\right.$ passenger $\left.\mathrm{km}\right]$} \\
\hline $\mathrm{ENO}_{\mathrm{x}} \mathrm{T}$ & $\mathrm{NO}_{\mathrm{x}}$ emissions of tram & [ $\mathrm{g} \mathrm{CO}_{2} /$ passenger $\left.\mathrm{km}\right]$ \\
\hline $\mathrm{EPM}_{10} \mathrm{~B}$ & $\mathrm{PM}_{10}$ emissions of bus & [ $\mathrm{g} \mathrm{CO}_{2} /$ passenger $\left.\mathrm{km}\right]$ \\
\hline $\mathrm{EPM}_{10} \mathrm{PV}$ & $\mathrm{PM}_{10}$ emissions of private vehicle & {$\left[\mathrm{g} \mathrm{CO}_{2} /\right.$ passenger $\left.\mathrm{km}\right]$} \\
\hline $\mathrm{EPM}_{10} \mathrm{~T}$ & $\mathrm{PM}_{10}$ emissions of tram & {$\left[\mathrm{g} \mathrm{CO}_{2} /\right.$ passenger $\left.\mathrm{km}\right]$} \\
\hline $\mathrm{FC}$ & fuel consumption in private vehicle & {$[1 / 100 \mathrm{~km}]$} \\
\hline $\mathrm{OC}$ & average occupancy in a private vehicle & [passengers/km] \\
\hline Opd & number of operation yearly operation days & {$[-]$} \\
\hline TR & traffic reduction & {$[\%]$} \\
\hline Ubi & users in each bus line & {$[-]$} \\
\hline Un & users in extreme tram stops & {$[-]$} \\
\hline
\end{tabular}

\section{Greek letters}

$\alpha$

$\beta$ traffic reduction due to the effect of the crisis

in 2009-2013

user's reduction in public transport due to

the effect of the crisis in 2009-2013 


\section{Abbreviations}

\begin{tabular}{|c|c|}
\hline $\mathrm{AECO}_{2}$ & Avoided emissions $\mathrm{CO}_{2}$ \\
\hline $\mathrm{AE}_{1 C O} \mathrm{CO}_{2}$ & Avoided Emissions $\mathrm{CO}_{2}$ in sub-impact 1 \\
\hline $\mathrm{AE} 2 \mathrm{CO}_{2}$ & Avoided Emissions $\mathrm{CO}_{2}$ in sub-impact 2 \\
\hline $\mathrm{AE} 3 \mathrm{CO}_{2}$ & Avoided Emissions $\mathrm{CO}_{2}$ in sub-impact 3 \\
\hline $\mathrm{AE} 1 \mathrm{CO}$ & Avoided Emissions CO in sub-impact 1 \\
\hline $\mathrm{AE} 2 \mathrm{CO}$ & Avoided Emissions $\mathrm{CO}$ in sub-impact 2 \\
\hline $\mathrm{AE} 3 \mathrm{CO}$ & Avoided Emissions $\mathrm{CO}$ in sub-impact 3 \\
\hline $\mathrm{AE}^{1} \mathrm{NO}_{\mathrm{x}}$ & Avoided Emissions $\mathrm{NO}_{\mathrm{x}}$ in sub-impact 1 \\
\hline $\mathrm{AE}^{2} \mathrm{NO}_{\mathrm{x}}$ & Avoided Emissions $\mathrm{NO}_{\mathrm{x}}$ in sub-impact 2 \\
\hline $\mathrm{AE} 3 \mathrm{NO}_{\mathrm{x}}$ & Avoided Emissions $\mathrm{NO}_{\mathrm{x}}$ in sub-impact 3 \\
\hline $\mathrm{AE}_{1 \mathrm{PM}} \mathrm{M}_{10}$ & Avoided Emissions $\mathrm{PM}_{10}$ in sub-impact 1 \\
\hline $\mathrm{AE}_{2} \mathrm{PM}_{10}$ & Avoided Emissions $\mathrm{PM}_{10}$ in sub-impact 2 \\
\hline $\mathrm{AE}_{3} \mathrm{PM}_{10}$ & Avoided Emissions $\mathrm{PM}_{10}$ in sub-impact 3 \\
\hline CBA & Cost Benefit Analysis \\
\hline DD & Daily Displacements \\
\hline DEA & Data Envelopment Analysis \\
\hline ENPV & Emission Normative in Private Vehicle \\
\hline ENB & Emission Normative in Bus \\
\hline ES & Energy Savings \\
\hline ES1 & Energy Saving in Sub-impact 1 - Traffic reduction \\
\hline ES2 & $\begin{array}{l}\text { Energy saving in Sub-impact } 2-\text { Commuter } \\
\text { transport system change from bus to tram }\end{array}$ \\
\hline ES3 & $\begin{array}{l}\text { Energy Saving in Sub-impact } 3 \text { - North and } \\
\text { south neighbourhood }\end{array}$ \\
\hline MCA & Multycriteria Analysis \\
\hline PMS & Performance Measurement System \\
\hline $\mathrm{T}$ & Traffic \\
\hline Ti2009 & $\begin{array}{l}\text { Traffic registered by a measuring traffic station } \\
\text { in } 2009\end{array}$ \\
\hline Ti2013 & $\begin{array}{l}\text { Traffic registered by a measuring traffic station } \\
\text { in } 2013\end{array}$ \\
\hline
\end{tabular}

\section{REFERENCES}

1. Agency, E. E., Urban Environment, 2014.

2. EMTA: Barometer, 2013.

3. Commission, E., White Paper, 2011.

4. EMTA: Barometer of Public Transport in European Metropolitan Areas, 2009.

5. Commission, E., Together towards Competitive and Resource-efficient Urban Mobility, 2013.

6. May, A. D., Encouraging Good Practice in the development of Sustainable Urban Mobility Plans, Case Stud. Transp. Policy, Vol. 3, No. 1, pp 3-11, 2015, https://doi.org/10.1016/j.cstp.2014.09.001

7. Carmona, G., Trams and other Economic Wastes (in Spanish), Madrid, Spain, 2015.

8. Caulfield, B., Bailey, D. and Mullarkey, S., Using Data Envelopment Analysis as a Public Transport Project Appraisal Tool, Transp. Policy, Vol. 29, pp 74-85, 2013, https://doi.org/10.1016/j.tranpol.2013.04.006

9. Lefèvre, B., Long-term Energy Consumptions of Urban Transportation: A Prospective Simulation of 'Transport-land uses' Policies in Bangalore, Energy Policy, Vol. 37, No. 3, pp 940-953, 2009, https://doi.org/10.1016/j.enpol.2008.10.036

10. Peng, B., Du, H., Ma, S., Fan, Y. and Broadstock, D., Urban Passenger Transport Energy Saving and Emission Reduction Potential: A Case Study for Tianjin, China, Energy Convers. Manag., Vol. 102, pp 4-16, 2015, https://doi.org/10.1016/j.enconman.2015.01.017 
11. Isabello, A., Pensa, S., Arnone, M. and Rosa, A., Reviewing Efficiency and Effectiveness of Interurban Public Transport Services: A Practical Experience, Transp. Res. Procedia, Vol. 1, No. 1, pp 243-252, 2014, https://doi.org/10.1016/j.trpro.2014.07.024

12. Rojas-Rueda, D., Nazelle, A., Teixido, O. and Nieuwenhuijsen, M., Replacing Car Trips by increasing Bike and Public Transport in the Greater Barcelona Metropolitan Area: A Health Impact assessment Study, Environ. Int., Vol. 49, pp 100-109, 2012, https://doi.org/10.1016/j.envint.2012.08.009

13. Abrate, G., Piacenza, M. and Vannoni, D., The Impact of Integrated Tariff Systems on Public Transport demand: Evidence from Italy, Reg. Sci. Urban Econ., Vol. 39, No. 2, pp 120-127, 2009, https://doi.org/10.1016/j.regsciurbeco.2008.05.014

14. Costa, Á., Ebert, S., Fernandes, R., Sochirca, E. and Stanislau, T., Impact Analysis of Managerial Decisions on the Overall Performance of a Public Transport Operator: The Case of STCP, Procedia - Soc. Behav. Sci., Vol. 111, pp 1250-1263, 2014, https://doi.org/10.1016/j.sbspro.2015.01.726

15. Aranda-Usón, A., Valero-Capilla, A., Zabalza-Bribian, I. and Scarpellini, S., Energy Efficiency in Transport and Mobility from an Eco-efficiency Viewpoint, Energy, Vol. 36, No. 4, pp 1916-1923, 2011, https://doi.org/10.1016/j.energy.2010.05.002

16. Moriarty, P. and Wang, S. J., Eco-efficiency Indicators for Urban Transport, J. Sustain. Dev. Energy, Water Enviroment Syst., Vol. 3, No. 2, pp 183-195, 2015, https://doi.org/10.13044/j.sdewes.2015.03.0015

17. Okafor, I. F., Ogechi-Unachukwu, G. and Okay-Odukwe, A., Measuring Energy Efficiency of the Public Passenger Road Transport Vehicles in Nigeria, Transp. Policy, Vol. 35, pp 319-325, 2014, https://doi.org/10.1016/j.tranpol.2014.05.014

18. Agostino, D., Steenhuise, B., Arnaboldi, M. and de Bruijn, H., PMS development in Local Public Transport: Comparing Milan and Amsterdam, Transp. Policy, Vol. 33, pp 26-32, 2014, https://doi.org/10.1016/j.tranpol.2014.02.007

19. Sauer, I. L., Escobar, J. F., da Silva, M. F. P., Meza, C. and Centurion, C., Bolivia and Paraguay: A Beacon for Sustainable Electric Mobility? Renew. Sustain. Energy Rev., Vol. 51, pp 910-925, 2015, https://doi.org/10.1016/j.rser.2015.06.038

20. Hwang, J. J., Sustainable Transport Strategy for Promoting Zero-emission Electric Scooters in Taiwan, Renew. Sustain. Energy Rev., Vol. 14, No. 5, pp 1390-1399, 2010, https://doi.org/10.1016/j.rser.2010.01.014

21. Singh, S., Jain, S., Tiwari, A. K., Nouni, M., Pandey, J. and Goel, S., Hydrogen: A Sustainable Fuel for Future of the Transport Sector, Renew. Sustain. Energy Rev., Vol. 51, pp 623-633, 2015, https://doi.org/10.1016/j.rser.2015.06.040

22. Malla, S., Assessment of Mobility and its Impact on Energy use and Air Pollution in Nepal, Energy, Vol. 69, pp 485-496, 2014, https://doi.org/10.1016/j.energy.2014.03.041

23. Kii, M. and Hanaoka, S., Comparison of Sustainability between Private and Public Transport considering Urban Structure, IATSS Res., Vol. 27, No. 2, pp 6-15, 2003, https://doi.org/10.1016/S0386-1112(14)60139-4

24. Cárdenas Rodríguez, M., Dupont-Courtade, L. and Oueslati, W., Air Pollution and Urban Structure Linkages: Evidence from European Cities, Renew. Sustain. Energy Rev., Vol. 53, pp 1-9, 2016, https://doi.org/10.1016/j.rser.2015.07.190

25. Bubeck, S., Tomascheck, J. and Fahl, U., Potential for Mitigating Greenhouse Gases through expanding Public Transport Services: A Case Study for Gauteng Province, South Africa, Transp. Res. Part D Transp. Environ., Vol. 32, pp 57-69, 2014, https://doi.org/10.1016/j.trd.2014.07.002

26. Tricker, R. C., Assessing Cumulative Environmental Effects from Major Public Transport Projects, Transp. Policy, Vol. 14, No. 4, pp 293-305, 2007, https://doi.org/10.1016/j.tranpol.2007.02.004

27. Mrkajic, V., Vukelic, D. and Mihajlov, A., Reduction of $\mathrm{CO}_{2}$ Emission and Nonenvironmental Co-benefits of Bicycle Infrastructure Provision: The Case of the University of Novi Sad, Serbia, Renew. Sustain. Energy Rev., Vol. 49, pp 232-242, 2015, https://doi.org/10.1016/j.rser.2015.04.100

28. Prud'homme, R., Koning, M., Lenormand, L. and Fehr, A., Public Transport Congestion Costs: The Case of the Paris Subway, Transp. Policy, Vol. 21, pp 101-109, 2012, https://doi.org/10.1016/j.tranpol.2011.11.002

29. TRANSyT, Metropolitan Mobility Observatory (in Spanish), 2014. 
30. Zaragoza, Urban Plan, Population Accesibility to Tram Lines 1 and 2 and Main Equipment (in Spanish), 2012.

31. Zaragoza Tram, Line 1 Data (in Spanish), 2014.

32. Commission, E., Covenant of Mayors for Climate and Energy, 2016.

33. Commission, E., Environment, 2016.

34. Lopez, D., The Tram Contributes to reduce up to $60 \%$ the Traffic in the City Centre (in Spanish), El Periodico de Aragón, 2013.

35. CTZ, Metropolitan Mobility Survey (in Spanish), 2007.

36. IDAE, Guide to Elaborate Sustainable Urban Mobility Plans (in Spanish), 2006.

37. DUCIT, Mobility Indicators Evolution (in Spanish), 2014.

38. Velasco, R., Heraldo de Aragón, Urban Buses have an Average Age higher than 10 years (in Spanish), 2014.

39. IDAE, Guide about Energy and Efficiency Consumption (in Spanish), 2011.

40. AUZSA, Bus Characteristics in 2009 and 2013, 2015.

41. ECOINVENT, Electricity Voltage Transformation from High to Medium Voltage, 2014.

42. City of Zaragoza, Traffic Flows in 2009, 2013 and 2015 (in Spanish).

43. City of Zaragoza, Polluting Gases measured by Emission measuting Stations in 2009, 2013 amd 2014 (in Spanish).

44. TomTom, European Traffic Index, 2014. 